\title{
FLEMING'S DEFENSE MECHANISMS IN \\ STEPHEN CRANE'S THE RED BADGE OF COURAGE
}

\author{
Adam Anshori \\ Islamic University of Indonesia
}

\begin{abstract}
This paper is an attempt to discuss the personality of Henry Fleming, a fiction character in the novel the "Red Badge of Courage. The problem statement in this paper is "What defense mechanisms which occur in Fleming's character"?

This study used American Studies theory by Robert Meredith which agrees that the American Studies approach needs more than one academic discipline. The reconciliation of academic discipline enables the writer uses psychological approach. According to Wilbur S. Scott the application of psychological knowledge can generate three kinds of study and analysis: a more precise language with which to discuss the creative process, a study of lives of authors, and the use of psychology to analyze fictional characters. The theories of psychology were taken from Sigmund Freud's Psychoanalysis: A General Introduction to Psychoanalysis (2002), Sigmund Freud's The Ego and The Id (1962), and Anna Freud's The Ego and Defense Mechanism (1948).

The result of the study shows that there are a total of 25 acts of defense mechanisms conducted by Fleming in this novel. Henry acts all of the ten defense mechanisms from Anna Freud's theory. The primary act of denial is refusing to accept the condition Henry is facing and even lying to his own comrades. The acts of regression are not to talk to his own comrades either to help or just ignoring his comrades. Most of the acts of fantasy are about the ideal war in Henry's perspective which in reality was far from it. In the acts of displacement, most are by blaming his comrades and his generals instead of the enemy. The act of sublimation is conducted by hiding his fear and projecting his confidence. In the act of projection, Henry is projecting his insecurities to his enemy and his generals. Henry's act of rationalization is by justifying his flee from the battle. Henry's act of intellectualization is by
\end{abstract}


letting his thought overcome his act. The act of repression is by forgetting the fact that he is dependant to someone. And in the last, the act of reaction formation is by attacking the enemy in order to hide his fears.

Key words: defense mechanisms, American Studies, psychological approach

\section{INTRODUCTION}

According to Lye (2003), literature is mimetic. It is the mirror of reality. It represents the reality of human life. The story in literature can be a representation of human life. The people in literature are the imitation of the people in reality. Therefore, literary work can serve as a medium to study human life. Many literary works are inspired by human beings' realities, such as life and death. Moody (in Iswalono, 203:3) says that literature brings the readers back to reality of human situation, problems, feelings, and relation. Reading literature can give readers the portrayal of human beings' life. Awork of literature may reveal deep psychological truths even though the author is not aware of his or her work's psychological implications. This novel is widely considering a psychological novel by many scholars. It is interesting to follow Fleming's process in becoming a mature person by dealing with many anxieties. According to Freud, anxiety is an unpleasant inner state that people seek to avoid. Anxiety acts as a signal to the ego that things are not going right. Freud identified three types of anxiety: 1). neurotic anxiety is the unconscious worry that we will lose control of the id's urges, resulting in punishment for inappropriate behavior, 2) reality anxiety is fear of real-world events. The cause of this anxiety is usually easily identified. For example, a person might fear receiving a dog bite when they are near a menacing dog. The most common way of reducing this anxiety is to avoid the threatening object and 3) moral anxiety involves a fear of violating our own moral principles. In order to deal with this anxiety, Freud believed that defense mechanisms helped shield the ego from the conflicts created by the id, superego and reality.

Based on the explanation above the writer wants to do the research focused on the psychological aspects of Fleming's personality. The writer is interested in analyzing the defense mechanisms of Fleming's personality in the novel. The study is focused on Fleming's personality. To support the analysis the writer should write about the elements of Freud's psychoanalysis, Freud's structure of personality, and Anna Freud's defense mechanisms. 


\section{THEORETICALAPPROACHAND RESEARCH METHOD}

This research is interdisciplinary so it involves other fields of study. Bradbury and Temperly state,

"The American studies theory involves the integration of more than one academic discipline... and that the use of the multi approaches would give a more comprehensive and accurate analysis" (22).

Robert Meredith agrees that the American Studies approach "cut across and includes the content of other disciplines" (74). Tremaine McDowell's theory consists of three reconciliation of time, of academic discipline and of space (82). The reconciliation of academic discipline enables the writer uses psychological approach. According to Wilbur S. Scott the application of psychological knowledge can generate three kinds of study and analysis: a more precise language with which to discuss the creative process, a study of lives of authors, and the use of psychology to analyze fictional characters. The psychological approach is useful to analyze the personality of Fleming's character in the novel.

The research is a content analysis research. The subject of this research is a novel written by Stephan Crane entitled The Red Badge of Courage as the source of data. Mainly, the data of this study were taken from Crane's The Red Badge of Courage. The theories were taken from Sigmund Freud's Psychoanalysis: A General Introduction to Psychoanalysis (2002), Sigmund Freud's The Ego and The Id (1962), and Anna Freud's The Ego and Defense Mechanism (1948). The units of this analysis are in form of sentences from each chapter taken from Crane's The Red Badge of Courage. The writer focused the analysis on the intrinsic element in each chapter relating to Henry Fleming's personality.

\section{ANNAFREUD'S DEFENSE MECHANISMS}

The defense mechanism emerges in order to protect the ego from so many anxieties. Without the defense mechanism, the anxiety can be a threat to mental health. The defense mechanism that is used unconsciously and in certain limitation brings no negative effects. However, the defense mechanism can easily become too strong and dangerous, so it needs a lot of mental effort to support the mechanism and the real problems that need to be resolved. The defense mechanism becomes a strategy to hide from anxiety. There are some kinds of defense mechanisms. Anna Freud described ten different defense mechanisms used by the ego. 


\section{Repression.}

It is the most common defense mechanism and the basic of many Freud's theories. In repression, undesired information is put away to the unconsciousness. Repression is truly a form of forgetting. A person may repress his or her thought in somehow in order not to face the painful feeling or memory. A person can really forget his or her experience after a traumatic event. His or her consciousness efforts to rememorize his or her experience give no result. This repression happens for emotional problem and trauma that caused by external occurrence such as war. Repression acts to keep information out of conscious awareness.

\section{Denial}

Denial is probably one of the best known defense mechanisms, used often to describe situations in which people seem unable to face reality or admit an obvious truth (i.e. "He's in denial."). Denial is an outright refusal to admit or recognize that something has occurred or is currently occurring. In denial, a person does not want to accept his or her real situation. Sometimes, denial can be accepted as a shortterm defense. In some cases, denial can endanger a person when he/ she never sufficiently face the real situation. Denial functions to protect the ego from things that the individual cannot cope with.

\section{Displacement}

It is a defense mechanism that commonly appears as a cause of repression. It happens to a person when he/ she cannot release his feeling such as anger. This defense mechanism is formed and then directed to other person, animal, or an object that completely has no relation with the original situation. Displacement involves taking out our frustrations, feelings and impulses on people or objects that are less threatening. Displaced aggression is a common example of this defense mechanism. Rather than express our anger in ways that could lead to negative consequences (like arguing with our boss), we instead express our anger towards a person or object that poses no threat (such as our spouse, children or pets).

\section{Projection}

This defense mechanism is nearly the combination of denial and displacement. It is the effect of repression that makes the person is unable to recognize the reality of his own attitude. Consequently, a taboo motive or mistake is projected to the 
external side, which is other person. Projection is a defense mechanism that involves taking our own unacceptable qualities or feelings and ascribing them to other people. Projection works by allowing the expression of the desire or impulse, but in a way that the ego cannot recognize, therefore reducing anxiety.

\section{Fantasy}

The mind is active and imaginative in the organization of its own experience. The imaginative activity is called fantasy. It plays a powerful role in the organization of one's experience. Fantasy is important since through fantasy, someone transforms his or her wishes, desires, and thoughts that cannot be fulfilled in the real life. Fantasy helps people to reconcile himself with reality. The effort to reconcile with reality is closely related with the projection. Mostly, people dream and have fantasy in the day time in certain measure in order to make the life easier to face. This can be a positive way, for example dreaming about a vacation to another country may motivate a person to work harder. Fantasy can be dangerous when the person can no longer differentiate between fantasy and reality. When this happens, the person may spend so much psychic energy just for dreaming. His or her concern is no longer directed to problems that can be obstacles to progress in the real life.

\section{Reaction Formation}

Reaction formation reduces anxiety by taking up the opposite feeling, impulse or behavior. An example of reaction formation would be treating someone you strongly dislike in an excessively friendly manner in order to hide your true feelings. Sometimes, a person feels the existence of an impulse and conceals it by the contradictory reality. For example, he acts friendly and nicely to the person that he actually hates and wants to harm. As a form of defense mechanism, reaction formation generally happens to teenagers. In this case, they tend to show hostility toward people whom they like. Problems will appear when the latent stimulation is still remained and unfinished. A great negative power then can be formed unintentionally.

\section{Regression}

When confronted by stressful events, people sometimes abandon coping strategies and revert to patterns of behavior used earlier in development. Anna 
Freud called this defense mechanism regression, suggesting that people act out behaviors from the stage of psychosexual development in which they are fixated. For example, an individual fixated at an earlier developmental stage might cry or sulk upon hearing unpleasant news. In regression, the person comes back to the earlier stage and attitude of his development where he feels secured and comfortable. Regression commonly happens to the children but it also happens to the adults. Sometimes, the adults fall into a bad regression after experiencing a bad trauma. They act childishly. Sometimes, when they face problems, they bend over their body like a fetus in the mother's uterus.

\section{Sublimation}

Sublimation is a defense mechanism that allows us to act out unacceptable impulses by converting these behaviors into a more acceptable form. For example, a person experiencing extreme anger might take up kick-boxing as a means of venting frustration. Freud believed that sublimation was a sign of maturity that allows people to function normally in socially acceptable ways.

\section{Intellectualization}

Intellectualization works to reduce anxiety by thinking about events in a cold, clinical way. This defense mechanism allows us to avoid thinking about the stressful, emotional aspect of the situation and instead focus only on the intellectual component. For example, a person who has just been diagnosed with a terminal illness might focus on learning everything about the disease in order to avoid distress and remain distant from the reality of the situation.

\section{Rationalization}

Rationalization is a defense mechanism that involves explaining an unacceptable behavior or feeling in a rational or logical manner, avoiding the true reasons for the behavior. For example, a person who is turned down for a date might rationalize the situation by saying they were not attracted to the other person anyway, or a student might blame a poor exam score on the instructor rather than his or her lack of preparation. Rationalization not only prevents anxiety, it may also protect self-esteem and self-concept. When confronted by success or failure, people tend to attribute achievement to their own qualities and skills while failures are blamed on other people or outside forces. 


\section{DISCUSSION}

This novel portrays Henry's growth and maturity as a soldier through the changes in his personality and behavior. During this transition, Henry's emotions changes dramatically from glory to fear to depression to anger to exhilaration to courage to honor. His personality and behavior move from innocence to experience, in essence from doubt to duty.

Henry's maturing process occurs very quickly. In only a few days, Henry experiences a lifetime's worth of growth from his enlisting for self-centered reasons of glory, to the exhilaration of his first battle, to his running from his second battle, for fear of being killed, and, ultimately, to his facing the enemy and leading a charge as he becomes one of the bravest soldiers in his regiment. Several examples from the novel illuminate the changes which take place in Henry's character and in their relationship to his defense mechanism. The defense mechanisms are based on Anna Freud's theory.

In chapter 1, the theme of the struggle between confidence and fear and doubt has a major portion. Henry is so sure about the glory awaiting him in war that he enlists despite his mother's wishes. His romantic vision of war convinces him that he must enlist in the army This shows the first sign of Henry's defense mechanism which is fantasy. However, this confidence quickly fades, and even in this first chapter, Henry struggles between his romanticized assurance and his lack of confidence about his untested performance.

Henry is almost entirely introspective in the first chapter, which sets the stage for following Henry's thoughts and emotions throughout the novel. Henry is describe as a young man who initially turns inward when confronted by death issues, develop the confidence necessary to be a frontline soldier. For Henry, initially, this imaginative behavior overrides his reasoning ability, and only time and experience will help him face the realities of war. This shows the act of intellectualization in which Henry sees the upcoming war on his own perspective. A part of this maturing process involves Henry's moving away from the questioning of his behavior and motivations, of his comrades' behavior and motivations, and of the officers' decisions and plans for battle.

In chapter 2, it continues to focus on Henry's internal conflict about his bravery. Henry is fixated on proving his courage and his obsession with the issue causes him to become distant and removed from the other members of the 
regiment. He feels like an outcast, as if he is strangely not like the other soldiers. Henry's feelings of isolation foreshadow his physical separation and retreat from the regiment later in the novel.

In chapter 3, the characterization of Henry is still consistent. His fears persist, and his self-doubt has not changed. His reactions to his environment both to the countryside and the Confederate soldiers become predictable. For example, when the regiment covered the same ground in both the morning and afternoon, Henry was comfortable the second time around because he had been there before. Henry's thoughts in this chapter continue to develop the themes of fear, doubt, duty, confidence, and glory, themes which have been apparent from the opening chapter.

Henry's reaction to entering new territory is predictable, especially considering that, for any soldier, entering new ground may bring combat. The troop movement described in this chapter is especially trying for Henry because entering of new ground could bring with it his first taste of combat. It is only natural, therefore that a new recruit would be very fearful of new territory and very comfortable covering old ground. The issue here is fear of the unknown, a fear common to all people, and soldiers face a higher price for venturing into the unknown than do regular citizens. As a soldier gains experience in covering new territory, he gains control of his fear. This shows the act of sublimation. This pattern of reducing fear through gaining experience characterizes Henry's transition throughout the novel.

Henry's youthful confidence reasserts itself in a strange way in this chapter. At one point, Henry fears even the shadows in the woods, and he concludes that he and his comrades are trapped. Henry blames the generals for allowing this to happen.

"The generals were idiots to send them marching into a regular pen.

There was but one pair of eyes in the corps" (Crane, 1993: 24).

This implies, of course, that Henry thinks that he knows more about waging war than the officers do. This act shows projection in Henry's personality. He is projecting his insecurities toward his generals. This observation comes from a soldier who has never been in a battle. Even so, this reaction is probably not unusual for a very nervous, worried young man who continues to anticipate an impending battle and all the dangers associated with it.

In chapter 4, the theme of fear, in this case fear of the unknown, grows because the soldiers do not see, and have not, as yet, seen, the enemy the force, the monster, 
causing all this chaos. Indeed, the fear of the unknown is greater than the fear of facing the enemy directly. This fear of the unknown is a normal human behavior, one with which all people can identify, and, as a result, we empathizes with Henry.

In chapter 5, once Henry hears the words, "Here they come!." (31) he is a changed soldier. Henry seems to totally forget the fears that have almost overwhelmed him up to this point in the novel.

Henry's reaction is the reaction of any soldier. If he is to fight, he must be energized and focused. This attack by the enemy has angered and exasperated him, and, as a result, he wants to remove this source of irritation, in this case the enemy. His fears are surpassed by his anger and frustration, and he fires his rifle repeatedly as a result. It is not until the enemy retreats that he realizes what he and his comrades have accomplished. This shows other defense mechanism in Henry's personality which is reaction formation. He actually feels fear, but instead he attacks the enemy in order to hide his fears.

In chapter 6, Henry cannot understand how the enemy can possibly regroup to do battle again so quickly. Crane reveals Henry's confusion in these words,

"He [Fleming] waited, as if he expected the enemy to suddenly stop, apologize, and retire bowing. It was all a mistake." (Crane,1993: 38).

He can't imagine that his regiment could, or would, do such a thing, and he speculates that the enemy can't really be a group of individual men similar to the men in his regiment. His thoughts show his increasing fear of the enemy as Crane tells the reader that

"He began to exaggerate the endurance, the skill, and the valor of those who were coming. Himself reeling from exhaustion, he was astonished beyond measure at such persistency. They must be machines of steel." (Crane, 1993: 39).

This act is showing denial. Henry cannot accept the fact that the enemy is more powerful than he thought. Henry's deteriorating physical condition foreshadows his eminent mental collapse.

"His neck was quivering with nervous weakness and the muscles of his arms felt numb and bloodless, His hands, too, seemed large and awkward as if he was wearing invisible mittens. And there was a great uncertainty about his knee joints" (Crane, 1993: 38). 
When the soldier next to him drops his rifle and runs, Henry's imagination takes total control over his reasoning ability, and he runs. This shows the defense mechanism which is rationalization. Henry is blaming someone else for his act of fleeing.

As Henry runs away from the front, he comes upon a meeting of officers, and he overhears the general discussing strategy with the other officers. There is no panic in the general's voice when he says,

"Tompkins, go over an' see Taylor, an' tell him not tbe in such an allfired hurry; tell him t' halt his brigade in th' edge of th' woods; tell him t' detach a reg'ment say I think th center'll break if we don't help it out some; tell himt' hurry up" (Crane, 1993: 42).

And later, when the officers hear that the regiment has repelled the enemy's offensive, the general says,

"Yes, by heavens, they've held 'im!. . We'll wallop 'im now. We've got 'em sure." (Crane, 1993: 42).

These comments show clearly the confidence and courage of the officers. Indeed, it is only when Henry overhears the rational observations of the general that he is able to suppress his panic and gain some level of stability.

In chapter 7, Crane develops Henry's character by allowing him to rationalize his behavior. After he retreats from the battle and the wild fear that caused him to run, he returns to a state of reason and relative stability. Henry dismisses any notion that his running was not the right thing to do by rationalizing that his comrades were fools to stay and die. Henry is angry with his comrades when he learns that they were not annihilated, but, rather, were victorious in battle. This shows another defense mechanism in Henry's personality which is displacement. Henry assumes that they are fools to continue to press their luck.

In his isolation, Henry attempts to find justification for his actions in nature. Henry contemplates that even the smallest of nature's creatures (in this chapter, a squirrel) knows when to run for safety.

"He threw a pine cone at a jovial squirrel, and he ran with chattering fear" (Crane, 1993: 44).

"The youth felt triumphant at this exhibition. There was the law, he said. Nature had given him a sign. The squirrel, immediately upon 
recognizing danger, had taken to his legs without ado. He did not stand stolidly baring his furry belly to the missile, and die with an upward glance at the sympathetic heavens....The youth wended, feeling that Nature was of his mind. She re-enforced his argument with proofs that lived where the sun shone." (Crane, 1993: 45).

Should not the most intelligent of nature's creatures, a human being, do the same? Henry's decision to rationalize his behavior when the behavior is outside the norm and his ability to rationalize his actions becomes important later in the novel.

In chapter 8, for human beings, as well as for natures other creatures, curiosity may be stronger than fear. Henry's curiosity gets the better of his fear. The battle sounds are too intriguing to ignore, so Henry reverses his retreat and heads back to the front. This return to the front, then, is not out of Henry character because it is a very normal reaction for any curious young person.

In chapter 9 , Henry possesses a state of reason that allows him to feel guilty about running away. He feels ashamed that he has no wound like the others around him. He longs to carry a symbol of bravery, a wound, indicating that a more normal sense of honor has returned to his mind. This shows the act of denial. Henry refuses to be in his current condition. He won't accept the fact that he is the only one who did not get any wound.

Because Henry has not been a leader, he has relied on his comrades to be his leaders. When Jim, a true leader for Henry, is wounded and dies, Henry turns inward, a behavior which he has followed throughout the work. Henry does this in an attempt to protect himself psychologically. This is showing the act of repression. He does not want his dependence on others to be obvious. This reaction has been a consistent dimension of Henry's character.

In chapter 10, Henry's reaction to the tattered man's whining is to abandon the disoriented soldier. It is showing the act of regression. Ironically, Henry doesn't recognize that he has been the one doing the greatest bleating (if only internally). When he sees that same behavior in another person, he treats that behavior with disdain unable or unwilling to show compassion or to see that same behavior in himself. Henry has sunk into a state of total self-absorption, the antithesis of the compassion required to be the courageous and honorable man he thinks he wants to be. 
After abandoning the tattered soldier in the field, Henry realizes that he is also alone and abandoned. Henry remains selfish, introspective, fearful, and doubtful.

In chapter 11, Henry's thoughts swing, in just a few pages, from elation to depression. At one moment, Henry fantasizes about how glorious it might be if he were to die in battle. This shows the act of fantasy. Then, in the next instant, he counts the many reasons why he can't join the battle. The realization that he can't go back to the battle, where he might face ridicule, sends him into a fit of self-loathing. This is again showing denial. Henry is close to not realizing what are the fact and the reality.

"He said that he was the most unutterably selfish man in existence."

(Crane, 1993: 63)

These swings in emotion reveal Henry's instability, an instability compounded by the actions which he has taken and by his deteriorating physical condition.

It is also interesting to note that it is not until this chapter that we discover Henry's full name Henry Fleming. The presentation of the full name comes through one of Henry's imagined encounters with his comrades this time when his comrades connect his name with his running away:

"Where's Henry Fleming? He run, didn't 'e? Oh, my!" (Crane, 1993: 64)

The use of Henry's full name indicates the strength of his fear of being discovered that as a runner; there is no place to hide when someone knows your full name.

In chapter 12, it is ironic, that the symbolic "red badge" which Henry receives in this chapter is not a symbol of courage but rather of question. In addition to it, the red badge is delivered, not by an enemy, but by a comrade. Throughout the novel, Henry has questioned everything why he joined, whether he will stand and fight or run, and so on. It is significant to Henry's characterization that his red badge is not the result of contact with a bullet, but of contact with a question.

Another ironic twist results when the cheery-voiced soldier returns Henry to his regiment. The soldier feels that he is removing Henry from danger, but for Henry, who has thought about all the negative ramifications of his returning to his regiment, returning to his regiment actually places him in danger. This shows the act of projection. The fact that Henry is "cheerily" delivered to his regiment is an 
ironic contrast to the sadness which he assumes must follow his explanation of his whereabouts.

"As he who had so befriended him was thus passing out of his life, it suddenly occurred to the youth that he had not once seen his face." (Crane, 1993: 70)

This realization is also important to Henry's characterization; Henry has the opportunity to look into the face of happiness, but he does not do so, because he is so engrossed in his own sadness and doubt. This act shows denial. He remains totally absorbed in himself even the unselfish help of the cherry soldier is not enough to jar Henry out of the conflict in his mind.

In chapter 13, the themes of doubt and duty are addressed in this chapter as seen in the company, as demonstrated through the behavior of Wilson and Simpson. They welcome the return of Henry without question. In their duties as soldiers and as friends, his comrades care for him, joyfully accepting his return.

Henry, on the other hand, responds to their kindness with doubt and lies. This is showing the act of denial. Henry doubts that his comrades can accept that he was overcome by fear and ran from battle, and, what's more, that they would forgive him for this breakdown. He chooses lies rather than face the possibility of ridicule and scorn.

"'Yes, yes. I've I've had an awful time. I've been all over. Way over on th' right. Ter'ble fightin' over there. I had an awful time. I got separated from th' reg'ment. Over on th' right, I got shot. In th' head.“ (Crane, 1993: 71)

Typically, Henry begins establishing his story with youthful confidence. But later, when his friend discusses his head wound further, Henry's glibness disappears, and he only fumbles with a button on his jacket in response. This act again shows denial. His initial glibness may disgust us and lead to the decision that Henry is not capable of true honor. His retreat from this glibness is a sign that Henry is ashamed of the lies and his rejection of duty, which shows hope that he can return to valor.

In chapter 14, Wilson, which is more known in the novel as the loud and practical soldier at the beginning, has become Wilson, the compassionate, caring, veteran soldier. Henry's reaction to this realization about his friend shows that he too is on the path toward change. Rather than resenting his friend's newfound calm, 
evidently brought on by confidence gained in battle, or comparing his friend's calm with his own lack of assurance and certitude, Henry simply accepts that his friend has changed, and he seems happy for him.

In chapter 15, Henry's rationalization of his actions and his delusions came to a climax end in this chapter. When Henry realizes that he still holds Wilson's letters, he is suddenly transformed into a powerful being. He takes his strength from Wilson's weakness. Indeed, in thinking about this packet of letters, Henry's "self pride was now entirely restored." Beyond that, he begins to believe that he really has accomplished something great. In his thinking, he builds his case for greatness to the point that "He returned to his old belief in the ultimate, astounding success of his life" and "He saw plainly that he was the chosen of some gods."

Henry has made a monumental shift in his position, a shift from doubt to confidence to duty, a shift which overtly is based upon delusion. The shift appears to have no basis in reality; however, for Henry, fantasy may be reality, and, if this is the case, this shift could be permanent. This is the act of fantasy. The fantasy which occurs here is a positive one. Henry uses his fantasy to motivate him to become better.

In chapter 16 , Henry vocalizes his new-found confidence by criticizing the generals who are leading the troops. On two occasions he calls the generals "derned old lunkheads." This is quite a confident statement from one which not so many hours ago had any confidence. This shows the act of displacement. Henry is blaming the generals instead accepting the fact that the troops were the ones to be blamed.

Moreover, Henry also talks about the great effort of these troops, and he includes himself in those efforts.

"Well, don't we fight like the devil? Don't we do all that men can? (Crane, 1993: 85)

The brigadier said he never saw a reg'ment fight the way we fought yestirday, didn't he? And we didn't do better than many another reg'ment, did we? Well, then, you can't say it's th' army's fault, can you?" (Crane, 1993: 85)

Again, Henry includes himself in this review, and since no one challenges his being a part of the fighting, he presses his point that their lack of success is the 
fault of their leaders. This again shows the act of displacement. Henry refuses to blame the regiment but instead always blaming on his generals if they act poorly.

At one point in his tirade Henry is challenged by a soldier who suggests that perhaps he fought the whole battle yesterday. This makes Henry revert to his fear mode, but when no one picks up on this challenge, Henry regains his confidence and continues his attack on what he considers to be their poor leadership. This shows the act of sublimation. Fleming is converting his fear into confidence.

In chapter 17 , Henry realizes that he is, in fact, a soldier and that he must kill or be killed. Henry becomes angry with the idea that the enemy never seems to tire.

"But those other men seemed never to grow weary; they were fighting with their old speed. He had a wild hate for the relentless foe." (Crane, 1993: 89)

This shows the act of projection. Henry is actually projecting his fear to the relentless enemy. But in the next act Henry is a changed person; he is now a soldier. Henry's character has evolves in most part in this battle situation.

"These incidents made the youth ponder. It was revealed to him that he was a barbarian, a beast. He had fought like a pagan who defends his religion" (Crane, 1993: 91)

Moreover, Henry comes to the realization that;

"By this struggle, he had overcome obstacles which he had admitted to be mountains. They had fallen like paper peaks, and he was now what he called a hero." (Crane, 1993: 91-92)

This is the new Henry, the soldier-hero. The new confidence that was born of a lie has finally become the truth.

In chapter 18, Henry, on realizing that there will be a charge, comes to the realization that he is really "insignificant." The entire regiment, in the eyes of one of the officers, isn't more than a "broom" needed to sweep out "some part of the woods." For the men of the 304th, however, this is their war, this is their first offensive, and they will do their best. It can be seen that the regiment is blindly willing to do what is considered their duty.

The characterization in this chapter focuses on the officers, who are realists. One of them calls the troops of the 304th "mule drivers," meaning that they are 
rough-and-tumble troops, not a smooth and polished unit of veterans. At the same time, however, the general of this division recognizes that these men are needed, and he shows both compassion and realism when he says,

"Get 'em ready, then. I'll watch developments from here, an' send you word when to start them. It'll happen in five minutes." (Crane, 1993: 95)

As the other officer salutes, the general adds;

"I don't believe many of your mule drivers will get back." (Crane, 1993:95)

Crane creates an implication of resolution with a touch of sorrow in this response, but the general must send men into battle knowing that many will die. This is his responsibility, his duty, and this decision must be his, so he makes it.

In chapter 19, Henry responds without hesitation to the signal to charge. Indeed, he charges with such enthusiasm that he is described as "an insane soldier." But Henry is not alone in his enthusiasm the other soldiers are also in a "frenzy made from this furious rush." (98)

"The men, pitching forward insanely, had burst into cheerings, moblike and barbaric... a mad enthusiasm that it seemed would be incapable of checking itself before granite and brass." (Crane, 1993: 98)

Henry's enthusiasm infects the other troops, and he is, indeed, the leader of the charge although he was behind the officers.

Henry's struggle between doubt and duty seems to have disappeared. There is no question that duty is the dominant force now motivating Henry. His actions and behaviors throughout the last two chapters have been courageous, indeed heroic. Henry is becoming the personification of the word duty.

In chapter 20, this chapter shows clearly how the unit's confidence, as a whole, is dependent on the confidence of individual soldiers. At the same time, Henry's willingness, indeed his eagerness, to be the flag bearer illustrates his courage and recognition of duty. His behavior can be coupled with the brave leadership of the lieutenant in leading the troops into battle and in protecting them when under attack. The actions of these two men help to build the confidence of the unit to the point that they can mount an offensive and eventually repel a counterattack. 
Henry works closely with a bold leader, the lieutenant. Henry holds the flag as a rallying point for the regiment. He dismisses a friend who loses his confidence as he tells him,

"Oh shut up, you damned fool!" (Crane, 1993: 105)

This shows the act of regression. Henry will not listen to whining men with a loser mentality.

In Chapter 21, when Henry and the regiment return to their lines after their charge, and after repelling the enemy's counterattack, they are greeted with derision by a waiting regiment. Henry's reaction is one of anger. We can see that Henry's anger approach the level of hate on other occasions in recent encounters with the enemy. Henry feels hate even to his fellow troops. He is an anger machine which could boil into hate for anything or anyone who challenges his courage or the courage of his regiment. It is again the act of regression. This is quite a change from the fearful, doubting Henry which we saw earlier in the novel.

At the same time, Henry is also characterized as a realistic soldier. When he reviews the actions of his regiment in terms of the territory covered in the charge, he realizes that the distances covered "were trivial and ridiculous." He considers that perhaps the criticism of his regiment by the other regiment is justified. When he sees his disheveled regiment "gulping at their canteens," he feels disgust for their weakness because he thinks of his own behavior and performance during the charge and is quite pleased. This is also the act of regression.

In chapter 22, Henry initially embraced the Greek ideal of dying in battle as a part of his romantic view of war as seen in his talk with his mother about enlisting. This is the act of fantasy. However, as he experiences war, he matures. The romanticizing Henry transforms into a realistic Henry first as he overcomes his fear in his first battle, then as he runs from his second battle, next, as he leads a charge against the enemy, and finally, as flag bearer, as he watches his comrades dying, and he wishes to honor them and, at the same time, to gain revenge on the name-calling general.

"It was clear to him that his final and absolute revenge was to be achieved by his dead body lying, torn and gluttering, upon the field." (Crane, 1993: 115)

Henry's wish is one of a veteran soldier, a wish that has moved Henry beyond his selfish, romantic view of dying in battle for personal glory to an understanding that 
death, whether in support of a cause or in support of comrades, isn't to be feared, but, in fact, is to be accepted as an act of love. This shows a mature Henry, a selfless, veteran who is a product of war experiences which have moved him to a level of maturity well beyond his chronological age. Henry is no longer a selfish, fearful rookie; he is now a confident, veteran team player.

In chapter 23, the men of Henry's regiment are in the full frenzy of battle, so much so that they seem to be propelled by a force outside themselves the force of combined commitment to task and duty. Their charge, in the face of an apparently impossible task, is the ultimate act of bravery.

Henry has but one goal, the symbolic act of capturing the opposing regiment's flag. He seeks the flag not for personal glory, but because, "He was capable of profound sacrifices, a tremendous death."

"The youth had centered the gaze of his soul upon that other flag. Its possession would be high pride." (Crane, 1993: 118)

When the flag is captured, not by Henry, but with Henry's help, at this point we can see that Henry is truly a hero.

In chapter 24, in this last chapter, Henry mentally reviews the three significant stages of his battlefield experience. Regarding his second battle and his subsequent flight from the front, Henry attributes that behavior to nothing more than "the wild mistakes and ravings of a novice who didn't comprehend." Indeed that is probably a fair assessment since he was not the first soldier to run, nor would he be the last, and he did recover his courage to make a fine impression on his lieutenant at the next battle. Indeed his captain identified him as a fierce "wild cat". Also, then, when he led the troops as flag bearer, he was very courageous and, rightly so, because he stared into the face of the enemy and didn't back down. Henry's actions show great courage.

\section{CONCLUSION}

Based on the analysis, the writer of this paper concludes that there are a total of 25 acts of defense mechanisms conducted by Henry in this novel. Henry acts all of the ten defense mechanisms from Anna Freud's theory. The results are as follows: 7 acts of Denial, 4 acts of Regression, 3 acts of Fantasy, 3 acts of Displacement, 2 acts of Projection, 2 acts of Sublimation, 1 act of Rationalization, 1 act of Intellectualization, 1 act of Repression and 1 act of Reaction Formation. 
The primary act of denial is refusing to accept the condition Henry is facing and even lying to his own comrades. The acts of regression are not to talk to his own comrades either to help or just ignoring his comrades. Most of the acts of fantasy are about the ideal war in Henry's perspective which in reality was far from it. In the acts of displacement, most are by blaming his comrades and his generals instead of the enemy. The act of sublimation is conducted by hiding his fear and projecting his confidence. In the act of projection, Henry is projecting his insecurities to his enemy and his generals. Henry's act of rationalization is by justifying his flee from the battle. Henry's act of intellectualization is by letting his thought overcome his act. The act of repression is by forgetting the fact that he is dependant to someone. And in the last, the act of reaction formation is by attacking the enemy in order to hide his fears.

\section{REFERENCES}

Benson \& Grove. Psychology for Beginners. Cambridge: Icon Books Ltd, 1998.

Blum, Gerald S. Psychoanalytic Theories of Personality. New York: McGraw Hill Book Company Inc, 1953.

Crane, Stephen. The Red Badge of Courage. Everyman, 1993.

Early, James (et. al.) American Literature (Classic Edition). New York: Harcourt Brace Jovanovich Inc, 1968.

Freud, Anna. The Ego and Defense Mechanism. New York: International University Press Inc, 1948.

Freud, Sigmund. Sigmund Freud's Psychoanalysis: A General Introduction to Psychoanalysis (translated by Ira Puspitorini). Yogyakarta: Ikon Teralitera, 2002

Freud, Sigmund. The Ego and The Id. New York: W.W. Norton \& Company, 1962

Freud, Sigmund. Beyond the Pleasure Principle. New York: W. W. Norton \& Company, 1975.

Freud, Sigmund. Civilization and Its Discontent. London: The Hogarth Press, 1953. 
Fromm, Eric. The Anatomy of Human Destructiveness. New York: Holt, Rinehart and Winston, 1973.

Hollitcher, Walter. Sigmund Freud: An Introduction. London: Routledge \& Kegan Paul Ltd, 1950.

Jones, Ernest. Paper on Psychoanalysis (fifth edition). London: Bailliere Tindal \& Cox, 1950

Lye, John. On the Uses of Studying Literature . http://brocku.ca/English/jlye/uses.html

Meredith, Robert. American Studies: Essay on Theory and Method. Ohio: Charles E Meril Publishing Co, 1968.

Mc Dowell, Tremaine. American Studies. Minnesota: The North Central Publishing Company, St Paul, 1948.

Mollinger, Nada, Robert. Psychoanalysis \& Literature: An Introduction To. Chicago: Nelson Hall Publisher, 1981.

Pervin, Lawrence A. Personality: Theory and Research (5th ed.). New York: John Wiley \& Sons Inc, 1989.

Salvatore, R. Maddy. Personality Theories: A Comparative Analysis (4th ed.). Illinois: The Dorsey Press, 1980.

Scott, Wilbur S. Five Approaches to Literary Criticism. New York: Collier Books, 1962.

Skipp, Francis E, et. al. American Literature. New York: Barron's Educational Series Inc, 1992.

Zastrow \& Karen. Understanding Human Behaviour \& the Social Environment. Chicago: Nelson Hall Publisher, 1987. 